\title{
Decoupled recovery of ecological communities after reclamation
}

\author{
Zachary A Sylvain ${ }^{\text {Corresp., } 1}{ }^{1}$, David H Branson ${ }^{1}$, Tatyana A Rand ${ }^{1}$, Natalie M West ${ }^{1}$, Erin K Espeland ${ }^{1}$ \\ ${ }^{1}$ Pest Management Research Unit, USDA - Agricultural Research Service, Sidney, MT, United States of America \\ Corresponding Author: Zachary A Sylvain \\ Email address: zach.sylvain@gmail.com
}

Grassland restoration is largely focused on creating plant communities that match reference conditions. However, these communities reflect only a subset of the biodiversity of grassland systems. We conducted a multi-trophic study to assess ecosystem recovery following energy development for oil and gas extraction in northern U.S. Great Plains rangelands. We compared soil factors, plant species composition and cover, and nematode trophic structuring between reclaimed oil and gas well sites ("reclaims") that comprise a chronosequence of two - 33 years since reclamation and adjacent, undeveloped rangeland at distances of $50 \mathrm{~m}$ and $150 \mathrm{~m}$ from reclaim edges. Soils and plant communities in reclaims did not match those on undeveloped rangeland even after 33 years. Reclaimed soils had higher salt concentrations and $\mathrm{pH}$ than undeveloped soils. Reclaims had lower overall plant cover, a greater proportion of exotic and ruderal plant cover and lower native plant species richness than undeveloped rangeland. However, nematode communities appear to have recovered following reclamation. Although total and omni-carnivorous nematode abundances differed between reclaimed well sites and undeveloped rangeland, community composition and structure did not. These findings suggest that current reclamation practices recover the functional composition of nematode communities, but not soil conditions or plant communities. Our results show that plant communities have failed to recover through reclamation: high soil salinity may create a persistent impediment to native plant growth and ecosystem recovery. 
1 Article title: Decoupled recovery of ecological communities after reclamation

2 Authors: Zachary A Sylvaina, David H Branson ${ }^{\mathrm{a}}$, Tatyana A Rand ${ }^{\mathrm{a}}$, Natalie M West ${ }^{\mathrm{a}}$ and Erin K 3 Espeland $^{\mathrm{a}}$

4 aPest Management Research Unit, USDA-Agricultural Research Service, Sidney, MT, United 5 States of America

6 Corresponding author: Zachary A Sylvain, zach.sylvain@gmail.com 


\section{Abstract}

Grassland restoration is largely focused on creating plant communities that match reference conditions. However, these communities reflect only a subset of the biodiversity of grassland systems. We conducted a multi-trophic study to assess ecosystem recovery following energy development for oil and gas extraction in northern U.S. Great Plains rangelands. We compared soil factors, plant species composition and cover, and nematode trophic structuring between reclaimed oil and gas well sites ("reclaims") that comprise a chronosequence of two 33 years since reclamation and adjacent, undeveloped rangeland at distances of $50 \mathrm{~m}$ and $150 \mathrm{~m}$ from reclaim edges. Soils and plant communities in reclaims did not match those on undeveloped rangeland even after 33 years. Reclaimed soils had higher salt concentrations and $\mathrm{pH}$ than undeveloped soils. Reclaims had lower overall plant cover, a greater proportion of exotic and ruderal plant cover and lower native plant species richness than undeveloped rangeland. However, nematode communities appear to have recovered following reclamation. Although total and omni-carnivorous nematode abundances differed between reclaimed well sites and undeveloped rangeland, community composition and structure did not. These findings suggest that current reclamation practices recover the functional composition of nematode communities, but not soil conditions or plant communities. Our results show that plant communities have failed to recover through reclamation: high soil salinity may create a persistent impediment to native plant growth and ecosystem recovery. 


\section{Introduction}

Restoration of human-degraded landscapes aims to recover ecological communities and their functions, and is critical for sustainable ecosystem management (Hobbs \& Harris, 2001). Conventional restoration focuses on reestablishing the most common members of the plant community (Suding, 2011), setting the stage for natural colonization of the area by other taxa (i.e., the "field of dreams" paradigm; Hilderbrand, Watts \& Randle, 2005). Restoration is intended to eventually reflect reference (e.g., undisturbed and natural) ecosystems, while reclamation may only restore a subset of reference conditions. Most studies of reclamation focus on individual ecosystem components; a multi-trophic approach is integral to understanding the interactions that influence or limit ecosystem recovery from disturbance.

Disturbed and reclaimed environments (hereafter referred to as "reclaims") present several impediments to the recovery of plant communities. Post-disturbance plant communities are often either depauperate (as in old-field systems) or lacking altogether (e.g., recent agricultural fields or surface mines), and native plant species must be seeded onto the site (i.e., assisted colonization, restoration, or reclamation). However, planted seed mixes have lower species diversity compared to the adjacent landscape (e.g., Simmers \& Galatowitsch, 2010). Additionally, undesirable (i.e., invasive, exotic, or ruderal) plants are often present in disturbed areas, either seeded intentionally during reclamation, incidentally by transport on machinery, or through natural colonization.

Numerous ecosystem components interact with plant communities to drive the ecosystem functions present in reference sites, such as soils and their communities (see Wardle et al., 2004; Sylvain \& Wall, 2011). Restoration and reclamation practices and studies often overlook soil 
50 characteristics and soil organisms (Snyder \& Hendrix, 2008). Soil organisms are intimately tied

51 to soil abiotic conditions and plant community composition and structure, with the latter being

52 especially important due to the dependence of soil food webs on plant-derived resources (i.e.,

53 litter inputs, root exudates and root material). Although plants are often seeded during

54 reclamation, soil biota are not commonly introduced (Lawrence et al., 2013) and must therefore

55 colonize from adjacent landscapes. Recovery of these communities is slow (Murphy \& Foster,

56 2014; Viall et al., 2014; Wodika \& Baer, 2015) and may depend upon soil microstructure and the

57 plant community (Baer, Heneghan \& Eviner, 2012). Among soil organisms, nematodes are a

58 group that may be particularly useful in monitoring studies (such as responses to disturbance and recovery) owing to their numerous interactions with plants and the soil habitat (Neher, 2001; Sylvain \& Wall, 2011). They are also easily extracted and sorted into functional/trophic groups (Yeates et al., 1993) and their trophic positioning, life history (especially lifespan relative to shorter-lived soil microbes) and sensitivity to environmental conditions facilitates their use in characterizing ecosystem conditions along disturbance gradients (Bongers \& Ferris, 1999; Neher, 2001). The broad span of trophic levels and comparatively longer lifespans of nematodes make them uniquely suited to use as indicators of environmental press dynamics such as those occurring during environmental recovery (as opposed to more transient pulse dynamics that strongly influence microbial communities). Nematodes involved in decomposition pathways (see Moore and de Ruiter, 2012) can respond to and even out the microbial responses to environmental pulses (such as ephemeral nutrient additions) and herbivorous nematodes can provide an indication of the prevalence of root material on which they feed (Neher 2001; Sylvain and Wall 2011). Together, these factors serve to reflect the state of nutrient cycling and revegetation dynamics and can be used to indicate how successfully restoration is progressing. 

event or as a consequence of management. For example, topsoil stockpiling and redistribution damages soil structure and depletes soil communities (Schuman, 2002; Menta, 2012).

Destruction of soil aggregates, increased infiltration rates, reductions in soil biota, and plant root growth into the stockpiled soil eventually leads to losses of carbon and nutrients, reducing accumulated topsoil productivity (Menta, 2012), although site to site variability is extremely high (Emam et al., 2014). Compaction during reclamation may also inhibit plant establishment and growth (Bassett et al., 2005). In addition to soil structural changes, several aspects of soils disturbed by stockpiling may contribute to the presence of environmental filters that impede recovery of plant and soil communities on restored areas. These can include comparatively low amounts of soil organic matter (Viall et al., 2014), leading to reduced nutrient availability for plant production. Subsoils are stockpiled separately from topsoils and in either stockpile type high salinity may result from integration of concentrated salt layers typical in this region (Espeland \& Perkins, 2013). semi-arid grasslands of central North America. Over the last few decades, increased development of these areas has resulted in an average of 50,000 new oil and gas wells per year (Allred et al., 2015), transforming the landscape. Oil and gas well sites are supported by road and pipeline infrastructure, creating a matrix of degraded habitat within rangelands, disrupting landscape connectivity and providing increased opportunity for introductions of undesirable species to both native rangeland and nearby cropland (Viall et al,. 2014; Preston, 2015). As a consequence,

94 Allred et al. (2015) estimated total productivity losses due to these activities at 10 Tg dry plant biomass. Reclamation could mitigate detrimental impacts (e.g., increased erosion, reduced water 
96 infiltration, species invasions) and return these landscapes to the productivity of reference sites.

97 Despite the importance of reclamation for the sustainable management of these landscapes, there

98 has been no systematic assessment of the mechanisms by which current oilfield reclamation

99 recovers the composition and functional structure of ecological communities and their

100 interactions.

We present one of the first studies to employ a multi-trophic assessment of reclamation outcomes. We examined reclamation in semi-arid grasslands following energy development in the Bakken oil and gas fields of western North Dakota, USA. We assessed whether reclamation has successfully returned soils or plant and nematode communities to reference conditions, comparing sampling locations on reclaims up to 33 years old with locations on adjacent, intact prairie both close to $(50 \mathrm{~m})$ and distant from $(150 \mathrm{~m})$ reclaim edges (“undeveloped rangeland"). We hypothesized that, (1) reclaimed plant communities would have greater cover of undesirable plant species, more bare ground and decreased species richness than adjacent, intact prairie. We also hypothesized that (2) undesirable plant species would increase on close intact prairie transects with time as they spread from reclaimed well sites. As a consequence of soil stockpiling and redistribution during reclamation activities, we hypothesized that (3) soil organic matter

112 (SOM) would decrease and that soil salinity and $\mathrm{pH}$ would increase on reclaimed sites compared to adjacent, undeveloped rangeland sites. We further hypothesized that (4) nematode community recovery on reclaims would be closely linked to patterns in soil conditions and plant community composition and structure across transects. Specifically, we predicted that nematode abundances would decrease as salinity and $\mathrm{pH}$ increased (less suitable habitat for nematode persistence);

117 reduced resource availability would reduce populations of root herbivorous nematodes (due to 118 reduced available root biomass as bare ground increased) and bacterivorous and fungivorous 
119 nematodes (due to reductions in SOM caused by increased bare ground and low litter cover).

120 Finally, because reclamation does not involve moving nematodes to a site in the way plants are

121 seeded into reclamations, we hypothesized that (5) nematode community recovery would lag that

122 of plant communities due to slower dispersal.

\section{Materials \& Methods}

124 Site selection and study design

125 We conducted field sampling within the northern half of the Little Missouri National

126 Grassland (between $47.404^{\circ} \mathrm{N}-47.743^{\circ} \mathrm{N}$ and $103.394^{\circ} \mathrm{W}-104.041^{\circ} \mathrm{W}$ ). This region of the

127 northern mixed-grass prairie in western North Dakota is characterized as wheatgrass-needlegrass

128 prairie (Barker \& Whitman, 1988) with mean annual precipitation of $387 \mathrm{~mm}$ and mean annual

129 temperature of $6.8^{\circ} \mathrm{C}$ (Aziz, Champa \& VanderBusch, 2006). We selected fourteen reclaimed oil

130 and gas well sites (hereafter "reclaims") on public land designated either "plugged and

131 abandoned" or "dry" with well and pipeline shapefiles provided by the North Dakota Industrial

132 Commission, Department of Mineral Resources, Oil and Gas Division (NDIC) using ArcGIS (v.

133 10.2.1, ESRI, Redlands, California, USA). Records on the seeding history of our sites were so

134 poor they were unusable; a variety of reclamation practices were likely employed, contributing to

135 variability in plant communities on reclaims. Sites were selected to have edges a minimum of

$136250 \mathrm{~m}$ from pipelines and access roads and to minimize cover of bare ground, rugged terrain

137 (e.g. draws and steep hillslopes) and creeping juniper (Juniperus horizontalis Moench) in order

138 to compare consistent plant types (e.g. grasses) and topography. Finally, sites that had

139 historically been tilled were excluded to avoid confounding effects of disturbances from sources

140 other than energy development. All map layers were exported from ArcGIS to Google Earth Pro 
141 (v. 7.1.4.1529, Google Inc., Mountain View, California, USA) prior to site selection. Our

142 selected reclaims ranged in age since reclamation (when a site was released from bond after

143 being deemed sufficiently revegetated for cattle exclosure fencing to be removed) from two to 33

144 years (Fig. S1).

145 In order to assess the effects of energy development and revegetation disturbance on 146 rangelands, $100 \mathrm{~m}$ transects were established on reclaims as well as on adjacent undisturbed 147 prairie at two distances, $50 \mathrm{~m}$ and $150 \mathrm{~m}$, from the reclaim edge. As the undisturbed prairie 148 transects have maintained continuous native prairie cover, these sites are all of a similar age with 149 each other and it is therefore only the reclaim sites that can be assigned to a particular "age" 150 since reclamation. At each of the 14 sites, three parallel transects were placed using Google 151 Earth followed by ground-truthing for final transect location ( $n=42$ transects). Transect 152 placement was designed to help detect potential movement of undesirable plant species from 153 reclaims into native rangeland or recolonization of reclaims by native rangeland species.

154

155

156

157

158

159

160

161

162

Plant and soil sampling

We sampled plant communities between 25 July and 25 August 2016. A Garmin GPSMap64st was used to identify the start and end points of the $100 \mathrm{~m}$ transect. At 15 evenly spaced points along the transect, on alternating sides, a $(20 \mathrm{~cm} \times 50 \mathrm{~cm})$ Daubenmire frame was placed at a random distance up to $7.5 \mathrm{~m}$. Within each frame, we measured plant species cover (Anderson, 1986) to the nearest 5\% increment (total cover could total $>100 \%$ ). Species were identified and determined to be native or exotic, and were further divided into invasive (exotics only) or ruderal (both natives and exotics), using Johnson \& Larson (2007), Larson \& Johnson (2007) and Stubbendieck, Hatch \& Butterfield (1997). It is important to note that both native and 
163 exotic plants can follow a ruderal life history strategy, and that not all exotic species are

164 necessarily invasive. Research showing the abundance of undesirable species in disturbed

165 habitats and eventual population expansion into adjacent sites has often not distinguished

166 between ruderal (e.g., Grime \& Mackey, 2002) and invasive species (e.g., Spellerberg, 1998;

167 Trombulak \& Frissell, 2000; Simmers \& Galatowitsch, 2010) though persistence of these

168 separate plant types has different implications for the health of reclaims. Although colonization

169 and persistence of ruderal species are associated with disturbance (Grime \& Mackey, 2002;

170 Espeland \& Perkins, 2017), invasive species are able to establish and persist, spread spatially,

171 and have detrimental ecological impacts in both undisturbed and disturbed environments (Dietz

172 \& Edwards, 2006; Richardson et al., 2000). Additional cover classes included bare ground and

173 litter. We sorted plants into functional groups including annual and perennial grasses, forbs,

174 shrubs and subshrubs (i.e., dwarf shrubs with persistent woody stems but seasonally-limited

175 herbaceous growth). At each Daubenmire frame location, a $6 \mathrm{~cm}$ diameter soil sample was

176 collected to a depth of $10 \mathrm{~cm}$ (i.e., the biologically active layer), and these samples were used to

177 create two bulk soil samples per transect (one bulk sample for each half of the $100 \mathrm{~m}$ transect) in

1781 gallon zip-top bags. Soils were returned to the lab, oven dried at $30^{\circ} \mathrm{C}$, sealed tightly with

179 excess air removed and shipped to Ward Laboratories, Inc. (Kearney, NE) for chemical and

180 physical analysis. Additionally, soil compaction was measured using a soil compaction tester

181 (agraTronix, Streetsboro, OH, USA) at 14 points along each transect at two depths, $7.5 \mathrm{~cm}$ and

$18215 \mathrm{~cm}$, and then averaged across each transect within each depth.

183 Nematode sampling

We collected soil samples for nematode analyses between 20 September and 28 October

2016. Each transect described above was used to create two contiguous $50 \mathrm{~m}$ x $20 \mathrm{~m}$ plots (i.e., 
186 two half-transect plots) centered along the $100 \mathrm{~m}$ transect. Ten soil cores $2.5 \mathrm{~cm}$ diameter and 10

$187 \mathrm{~cm}$ depth were collected from locations placed haphazardly and aggregated into a single bulk

188 sample, sealed in zip-top bags with excess air removed and transported to the laboratory in

189 coolers. These bulk samples were subsampled for nematode extraction and soil moisture

190 measurement. Nematodes were extracted using the Baermann funnel method (Baermann, 1917)

191 with $50 \mathrm{~g}$ of soil over $72 \mathrm{~h}$, and soil moisture was determined gravimetrically using $50 \mathrm{~g}$ soil

192 heated to $105^{\circ} \mathrm{C}$ for 48 hours in an oven and calculating mass loss due to evaporation (Barrett et

193 al., 2008). Live nematodes were counted and assigned to trophic groups according to Yeates et

194 al. (1993) using an Olympus CKX53 inverted microscope at 100 - 200x and were then preserved

195 in 5\% formalin solution. Although extraction using Baermann funnel has been shown to have

196 certain drawbacks in the efficiency with which the method recovers certain nematode groups

197 (generally being biased in favor of extracting greater numbers of smaller and more active

198 individuals; Freckman, Mankau \& Ferris, 1975), other methods also show biases in extraction

199 efficiency (see McSorley and Frederick, 2004). For broad ecological studies such as ours where

200 advantages of one method over another are unclear, Baermann funnel extraction is a commonly

201 used approach (e.g., Garcia-Palacios et al., 2017; Sylvain \& Mosseler, 2017; Andriuzzi \& Wall,

202 2018).

203 Analyses

Prior to analyses, nematode counts and soil chemical and physical characteristics were

205 averaged to yield single values per transect. Plant cover was averaged across all frames within

206 each transect. Nematode abundances were standardized to number of individuals per kilogram

207 dry soil (using gravimetrically determined soil moisture content). Additionally, an aggregate

208 trophic grouping of "omnicarnivores" was calculated by summing omnivore and predator 
209 abundances. We performed indicator species analysis using the labdsv package (Roberts, 2016).

210 This analysis identifies species characteristic of predetermined groups of sites (Dufrene and

211 Legendre, 1997), and we used this approach to select a subset of plant species characteristic of

212 sampling locations in our study (i.e. reclaims, and undeveloped rangeland at $50 \mathrm{~m}$ and $150 \mathrm{~m}$

213 distances from reclaims) for use in subsequent analyses (species with a significant indicator

214 value $\geq 0.45$ ). Plant species identified as indicators using this analysis included two from

215 undeveloped rangeland, Carex filifolia (native sedge, $150 \mathrm{~m}$ sampling location) and Bouteloua

216 gracilis (native grass, $50 \mathrm{~m}$ sampling location), and four from the reclaims, Elymus trachycaulus

217 (native grass), Agropyron cristatum (exotic and invasive grass), Medicago lupulina (exotic and

218 ruderal forb) and Distichlis spicata (native grass).

Analyses were conducted in R version 3.2.4 (R core development team, 2016) and all data were tested to meet assumptions of normality using QQ plots and the Shapiro-Wilk test; where data were found to be non-normal, response variables were transformed using either log

$222(\mathrm{x}+1)$ or square root transformations. Code used for all analyses is available at GitHub

223 (https://github.com/Ofmitesandmen/Bakken-plants-soils). All analyses on plant data were

224 conducted on the most commonly encountered species (present in $>5 \%$ of sampling quadrats).

225 We used mixed-model ANOVA to address hypotheses related to plant (H1), soil property (H3)

226 and nematode (H4) responses to energy development and reclamation. Testing was carried out

227 using the lme4 package (Bates et al., 2015), and the Kenward-Roger approximation was used to

228 calculate degrees of freedom for F statistics and associated P-values in the lmerTest package

229 (Kuznetsova, Brockhoff \& Christensen, 2016) using type III sums of squares. Our models used 230 sampling location (i.e., transects on reclaims or on undeveloped rangeland at 50 and $150 \mathrm{~m}$ from 231 reclaim edges) as a fixed effect and site as a random blocking effect in order to control for 
232 landscape variation between sites; response variables included plant species richness (total,

233 native and exotic), plant cover (natives, exotics, invasives, ruderals, total grasses, total forbs and

234 species identified using indicator species analysis), bare ground, soil abiotic factors (salts, $\mathrm{pH}$,

235 CEC, SOM, nitrate, texture and compaction) and nematode abundances (total and individual

236 trophic groups). Post-hoc tests were carried out using the multcomp package (Hothorn, Bretz \&

237 Westfall, 2008) and adjusted using the Holm method.

Regression testing was carried out using the base R statistics package. To address

whether undesirable plants increased with time since reclamation on undeveloped rangeland

(H2) and whether nematode community recovery lagged that of the plant community (H5), we

ran an initial set of regression models exploring potential interactions between distance from

reclaims (using transect type as an ordinal variable with the reclaim set at 0 ) and time since

reclamation. As undisturbed prairie transects (at $50 \mathrm{~m}$ and $150 \mathrm{~m}$ from reclaim edges) represent

sites that have not undergone conversion from native prairie, these analyses enabled us to determine whether native plants have moved from undisturbed prairie to recolonize reclaims

over time as well as whether invasive and exotic plants have moved from reclaims onto undisturbed prairie over time since reclamation (Fig. S1). These regressions used the same response variables as in ANOVA testing. A second set of regression models was run to test hypotheses regarding the relationships among soils, plants, and nematodes (H4). For these models, response variables included all plant and nematode variables tested with ANOVA, and predictors included soluble salt concentrations, SOM, \% silt, CEC, and soil $\mathrm{pH}$. For nematodes,

252 predictor variables also included cover of selected plant indicator species, namely crested 253 wheatgrass (Agropyron cristatum [L.] Gaertn.), blue grama (Bouteloua gracilis [Willd. ex

254 Kunth] Lag. ex Griffiths), threadleaf sedge (Carex filifolia Nutt.), bare ground and litter. All final 
255 ANOVA and multiple regression models were determined using backward selection and AIC

256 model comparisons to select the most parsimonious model that best fit the data; initial and final

257 models are included in relevant tables.

Nonmetric multi-dimensional scaling (NMS) ordinations using the Bray-Curtis distance

259

260

261

262

263

264

265

266

267

268

269

270

271

272

273

274

275

276

277

To further explore direct and indirect relationships between plants, soils and nematodes (H4), we constructed a Structural Equation Model (SEM) using the lavaan package (Rosseel, 2012). SEM is a multivariate analytical approach employing path and factor analyses to compare hypothetical models with data (Grace, 2006). Path coefficients are calculated for each set of connected variables in the model, representing the effect of a one standard deviation change in the independent variable on the dependent variable (if all other variables are held constant; Mitchell, 1992). Goodness-of-fit for hypothetical models is compared using $\chi^{2}$ statistics, with non-significant $(\mathrm{P}>0.05)$ values indicating adequate fit between model and data, supporting the null hypothesis represented by the model (Mitchell, 1992). We constructed our initial hypothetical model to represent broad plant community groups (ruderal plants and both native and exotic non-ruderal plants, hereafter simply "natives" and "exotics"), soil variables shown to have strong influence on the biotic community (salts and SOM), the amount of bare ground and litter within transects (common non-plant cover factors), and a nematode community summary variable (created from the first axis of a PCA using nematode community data; $37 \%$ variation explained). Our initial model (Fig. S2) represented a saturated interaction web and our final 
278 model was constructed iteratively by adapting best-fit models until a model having both a solid

279 mechanistic basis and good fit was found.

280 Results

281

282

283

284

285

286

287

288

289

290

291

292

293

294

295

296

297

298

299

Plant community dynamics

We identified 62 native plant species and 11 exotic plant species (common species listed in Table S1). Indicator species analysis identified one species characteristic of $150 \mathrm{~m}$ transect type, one characteristic of $50 \mathrm{~m}$ transect type, and 4 characteristic of reclaim transects (including exotic, invasive, and ruderal plant species; Table S2, Fig. 1). ANOVA testing (Table 1) revealed that total plant species richness was lower on reclaims compared to undeveloped rangeland, driven by lower native plant species richness on reclaims (Fig. 2a). Exotic plant species richness was greater on reclaims than on undeveloped rangeland (Fig. 2b). Native plant species cover was also significantly lower on reclaims compared to undeveloped rangeland (Fig. 2c), with exotic plants making up a correspondingly greater proportion of cover on reclaims. Reclaims also had more bare ground (Fig. 2d) and ruderal plant cover (Fig. 2e) and lower cover of grasses (Fig. 2f) compared with undeveloped rangeland. All the ruderals commonly found in our sampling locations were forbs. No significant differences were observed for invasive plant cover across sampling locations. Regression analyses found no effect of time since reclamation on plant community variables except for exotic species richness, where a significant interaction between time since reclamation and distance from reclaims was found $\left(P=0.0019, \mathrm{R}^{2}=0.27\right)$. This interaction is likely explained by a decrease in exotic species richness with time on the $150 \mathrm{~m}$ sampling locations $\left(\mathrm{P}=0.018, \mathrm{R}^{2}=0.39\right)$ and a suggestive (but not significant) trend $(\mathrm{P}=0.094$, $\mathrm{R}^{2}=0.22$ ) of increasing exotic species richness with time on reclaims. NMS ordination of plant 
300

301

302

303

304

305

306

307

308

309

310

311

312

313

314

community species composition revealed clear differences between communities associated with reclaims and those associated with undeveloped rangeland (three-dimensional final stress, 0.167 ;

first two dimensions shown, Fig. 3), which PERMANOVA analysis revealed to be significant (P $=0.003$ for both native prairie locations compared with reclaims). Similar results were obtained for plant community functional composition (three-dimensional final stress, 0.127 , PERMANOVA $\mathrm{P}=0.003$ for both undeveloped rangeland locations compared with reclaims). PERMDISP analysis revealed significant differences in dispersion about sampling location centroids when comparing plant species composition between undeveloped rangeland locations with reclaims (adjusted $\mathrm{P}=0.0004$ for $50 \mathrm{~m}$ and 0.04 for $150 \mathrm{~m}$ undeveloped rangeland locations), but not when comparing the two undeveloped rangeland locations with each other (adjusted $P=0.2$ ). No significant differences in dispersion were found for plant guilds (adjusted $\mathrm{P}=0.1$ for both undeveloped rangeland locations when compared with reclaims and 1 when comparing undeveloped rangeland locations with each other). Graphic examination of PERMDISP results suggest that while communities are distinct at the species level (the findings of PERMANOVA), reclamation decreases the heterogeneity of plant communities.

\section{Soil characteristics and nematode community dynamics}

Several soil chemical characteristics differed significantly between reclaims and undeveloped rangeland as revealed by ANOVA testing (Table 2). CEC, soluble salts, $\mathrm{Ca}, \mathrm{Na}$ and $\mathrm{pH}$ were all higher and \% silt was lower on reclaims compared with undeveloped rangeland (Fig. 4). Compaction at $15 \mathrm{~cm}$ (but not $7.5 \mathrm{~cm}$ ) was significantly greater on reclaims compared with undeveloped rangeland. No differences were found among transects for SOM or soil nitrate. Regression analyses revealed no significant changes to soil abiotic factors with time since 
322 reclamation, except for increased compaction at $7.5 \mathrm{~cm}\left(\mathrm{P}=0.03, \mathrm{R}^{2}=0.35\right)$ and a suggestive

323 (but not significant) increase in compaction at $15 \mathrm{~cm}\left(\mathrm{P}=0.054, \mathrm{R}^{2}=0.28\right)$.

324

325

326

327

328

329

330

331

332

333

334

335

336

337

338

339

340

341

342

343
Despite observed differences in soil properties between reclaims and undeveloped rangeland, few differences were observed for nematodes (Table 3; Table S3). Total nematode and omnicarnivorous nematode abundances significantly increased from reclaims to $150 \mathrm{~m}$ transect types, with abundances on the $50 \mathrm{~m}$ transects intermediate to both (Fig. 5). No other nematode trophic group differed between reclaims and undeveloped rangeland. Despite the differences observed in omnicarnivore and total nematode abundances, neither NMS ordination nor PERMANOVA analysis revealed differences in nematode community structure between reclaims and undeveloped rangeland, and regression testing revealed no interactions between distance from reclaim edge and time since reclamation (although bacterivorous nematodes increased with time on all transect types; $\mathrm{P}=0.03, \mathrm{R}^{2}=0.12$ ).

Interactions between abiotic factors and the biotic community

Regression analyses were used to test hypotheses regarding the relationship among soils, plants and nematodes. There were few strong relationships and in some instances no relationship was found (Table 1). The strongest relationships $\left(\mathrm{R}^{2}>0.30\right)$ involved: bare ground increasing with salt concentrations and soil $\mathrm{pH}$ but decreasing with SOM; grass cover increasing with SOM but decreasing with salt concentrations; and native plant richness decreasing with greater proportional cover of exotic plants. Salt concentrations and SOM were most commonly related to abundances of plant species highlighted with indicator species analysis, while forbs were the only plant group to respond to changes in soil texture (decreasing as the proportion of silt declined). There were significant relationships between nematode abundances and a combination 
344 of soil and plant community variables, although total variance explained by the models was

345 generally low $(15-22 \%$, Table 3$)$. Total abundance of nematodes increased with soil $\mathrm{pH}$ but

346 decreased with increasing bare ground, as did abundance of root herbivorous nematodes. Both

347 bacterivorous and fungivorous nematode abundances increased with SOM, while

348 omnicarnivorous nematodes increased with threadleaf sedge, the sole group where abundance

349 was related to a specific plant.

We used SEM analysis to examine direct and indirect interactions between a subset of

soil variables shown to strongly influence the biotic community, a summary variable for

352

353

354

355

356

357

358

359

360

361

362

363

364

365

nematode community, several important plant groups (ruderals, natives and exotics), and other

common non-plant ground cover types related to plant cover and disturbance (litter and bare ground). Our initial model (Fig. S2) did not provide a good fit to the data $\left(\chi^{2}=37.88, \mathrm{df}=7, \mathrm{P}<\right.$ 0.001), and was simplified using an iterative process to find the best fit model (Fig. $6 ; \chi^{2}=3.88$, $\mathrm{df}=7, \mathrm{P}=0.794)$. Among plant community groups, exotic plants were positively affected by SOM and increased amounts of bare ground, and were negatively affected by native plants. Ruderal plants were positively affected by increased salt concentrations and cover of bare ground. The nematode community did not respond to changes to the plant community groups, but was negatively affected by increased amounts of bare ground. Strengths of the direct effects are summarized in Table S4. Our model also revealed that SOM and bare ground indirectly influence native plants, mediated through direct interactions with exotic plants. The magnitude of the indirect effect of SOM on native plants $(-0.61=0.69 *-0.89)$ was roughly equivalent to the magnitude of the corresponding direct effect, while the magnitude of the indirect effect of bare ground on native plants $(-0.35=0.39 *-0.89)$ was twice as strong as the corresponding direct 
366 effect. The final model explained a large amount of variation in community variables: $76 \%$ for

367 native plants, $44 \%$ for ruderal plants, $42 \%$ for nematodes, and $34 \%$ for exotic plants.

368 Discussion

369

370

371

372

373

374

375

376

377

378

379

380

381

382

383

384

385

386

387

This study is one of the first to integrate plant and soil communities with soil

characteristics in an assessment of reclamation following energy development for oil and gas

extraction. Our data demonstrate that legacies of energy development are still clear in rangelands of western North Dakota, even after 30 years. Soil conditions on reclaims differed from those on adjacent, undeveloped rangeland primarily due to higher $\mathrm{pH}$ and salt concentrations and a lower proportion of silt. Plant communities on reclaims had lower total cover (i.e., more bare ground) and greater cover of undesirable plants. There was limited movement of native plants onto reclaims or of invasive or ruderal plants into surrounding rangelands. These results suggest that reclamation has not succeeded in recovering rangeland plant communities or soil conditions. The reduced productivity and greater bare ground cover in reclaims leads to reduced forage availability for livestock and wildlife, as well as increased potential for erosion that can then spread to adjacent lands. In contrast to soils and plants, the functional structure of nematode communities appears to have largely recovered to the reference levels demonstrated by surrounding rangeland.

\section{Plant community dynamics}

While their exact components are unknown, the reclamation seed mixes likely included crested wheatgrass and smooth brome (Bromus inermis Leyss.), which were commonly used by the US Forest Service (USFS), Bureau of Land Management (BLM) and other groups during reclamation and revegetation; the USFS used these grasses (despite being exotic and invasive) 
388 until recently, while the BLM continues to use crested wheatgrass in severely degraded sites.

389 These grasses are native to Eurasia, and were introduced to grasslands of the US in the early $20^{\text {th }}$

390 century because of their suitability as cattle forage and their ability to rapidly revegetate

391 abandoned cropland and eroded landscapes. Although suitable as forage during the growing

392 season, these grasses differ from many native species in their resource storage strategies, and

393 consequently provide less nutritious forage (for both livestock and wildlife) throughout the

394 winter, requiring protein supplementation (NRCS, 2006). Despite the likely, though unknown,

395 variation in seeding history, our results demonstrate that plant communities on reclaims were

396 clearly distinct from those on adjacent undeveloped rangeland as we hypothesized (H1).

397 Reclaims had more bare ground, and lower native plant species richness and cover. Given the

398 age of some of these reclaimed sites it is noteworthy that these plant communities still contain

399 ruderal species (e.g., black medick, curlycup gumweed and dandelion), which are relatively

400 uncommon regionally in undeveloped rangeland communities (Espeland \& Perkins, 2017). After

401 an initial increase, ruderal species are expected to decline as the restoration environment

402 becomes more competitive (e.g. Pywell et al., 2003; Espeland \& Perkins, 2017); relatively higher

403 ruderal cover in reclaimed sites suggest that competitive dynamics do not drive the low cover

404 and richness of native species.

Reclaims had reduced native plant species cover, especially for threadleaf sedge and blue

406 grama, the two most common species on undeveloped rangeland. Native plant establishment

407 onto reclaimed sites may be impaired due to a combination of dispersal and seed limitation as

408 well as reduced capacity for establishment. Because blue grama establishes easily when seeded

409 (Espeland et al., 2017), it is unlikely that it is limited by microsite availability. For this and

410 similar species, their absence from reclaims may simply result from dispersal limitation and 
411 suggests these plants may recover their abundance on reclaims only when seeded. We also found 412 inland saltgrass (Distichlis spicata [L.] Greene) on reclaims - it is often found in reclamations

413 but is rarely planted due to high dormancy and seed expense. The presence of this species when

414 absent from surrounding rangeland would suggest effective long distance dispersal to suitable

415 habitats. Native species in the Great Plains have different dispersal abilities that underlie the

416 degree to which propagule supply drives their colonization of reclamations, and soil factors may

417 influence the suitability of habitat conditions and establishment success. Similar to our results on

418 reclaimed well sites, roadside reclamation in this region often fails to recover the full suite of

419 native plant species found in surrounding rangeland (Simmers \& Galatowitsch, 2010), but

420 whether this lack of recovery is due to dispersal or establishment limitation is unclear.

Native species generally do not move onto reclaims, and undesirable plants do not move

422 from reclaims into adjacent rangelands, contrary to our second hypothesis that undesirable plants

423 would increase on intact rangelands with time. Given the amount of time available for these

424 plants to have dispersed from older reclaims into adjacent rangeland communities, it is likely that

425 intact rangeland plant communities in our study are sufficiently competitive (or microsite

426 availability is sufficiently limited) to have prevented establishment of undesirables such as

427 crested wheatgrass, confining them to the reclaims. The only effect of time since reclamation

428 was an interaction between distance from reclaim edges and time, demonstrated by a decrease in

429 exotic plant richness on the $150 \mathrm{~m}$ transects with time. Competition may limit the establishment

430 and spread of undesirable species from reclaims into undeveloped rangeland, as these transects

431 are furthest from direct impacts of energy development. A caveat to this is that invasive plant

432 cover did not differ between sampling locations in our study, primarily due to the prevalence of

433 Kentucky bluegrass in rangelands of western North Dakota. This invasive grass was relatively 
434 common on our undeveloped rangeland locations but almost entirely absent from reclaims,

435 suggesting that environmental filters may further limit plant establishment in reclaims.

436

437

438

439

440

441

442

443

444

445

446

447

448

449

450

451

452

453

454

455

456

\section{Soil characteristics}

Soils on reclaims differed from those of undeveloped rangeland, which supports our third hypothesis. While reclaim soils had greater CEC (generally used as a measure of soil fertility), they also had higher concentrations of salts (sodium and calcium); this increase in base cations also resulted in an associated increase in $\mathrm{pH}$. Soil management may be one cause of the greatly increased salt content of reclaim soils. During well construction, topsoil is scraped from the site and stockpiled nearby. The depth of topsoil excavation is determined to avoid the subsurface concentrated salt layer. However, subsoils are also stockpiled for berm construction and contouring the final reclamation; hence, subsoils are mixed as well as topsoils. The concentrated salt layer present in either of the soil layers is distributed throughout the soil volume during reclamation. Because the layer is no longer concentrated, plants cannot avoid it via root growth. Salinity also influences $\mathrm{pH}$, one of the strongest environmental factors governing soil microbial community composition and structure (Fierer \& Jackson, 2006). Given the levels of salinity observed on reclaims, it is possible plant recovery is limited both directly via the influence of salinity and indirectly due to altered microbial contributions to nutrient cycling dynamics (Emam et al., 2014). There does not appear to be any change in soil conditions with time since reclamation except for an increase in soil compaction at $7.5 \mathrm{~cm}$. This increased compaction occurred in all transect types and likely reflects cattle grazing or some other factor common to these landscapes. Soil texture on reclaims does not vary with time; the lower proportion of silt in reclaim soils relative to undeveloped rangelands suggests that losses to erosion may occur early in reclamation. 


\section{Nematode community dynamics}

458

459

460

461

462

463

464

465

466

467

468

469

470

471

472

473

474

We found few differences in nematode communities between reclaims and adjacent rangeland. Total nematode abundances were lower on reclaims, as were abundances of omnicarnivores. Part of this variation is likely due to greater prevalence of bare ground on reclaims relative to surrounding rangeland (Wall-Freckman \& Huang, 1998). This limits feeding substrates for root herbivorous nematodes and root exudates that support the bacterial and fungal populations upon which bacterivorous and fungivorous nematodes feed. Despite increases in omnicarnivorous and total nematode abundances from reclaims to $150 \mathrm{~m}$ transects, it is unclear whether these changes are due to movement of nematodes onto reclaims as only bacterivorous nematodes changed with time since reclamation. This increase with time was found across all transect types. While these differences partly support our fourth hypothesis (H4) that nematode community recovery would be linked to soil conditions and plant community composition, NMS ordination and PERMANOVA results indicate that the trophic structuring and composition of nematode communities are not significantly dissimilar between reclaims and undeveloped rangelands. These results suggest that, contrary to our hypothesis (H5) that nematode communities would recover more slowly than plant communities, nematode community functional composition may be largely recovered following reclamation, while soils, plant community composition, and bare ground show no signs of recovery to reference conditions.

Soil communities along a mining chronosequence in Wyoming also appear to recover rapidly, as communities in even young sites (two - five years post-mining) were found to be similar to reference sites (Frouz et al., 2013). The authors ascribed these results to revegetation rapidly recovering climax plant communities, dominance of the nematode community by root herbivores and the broadly similar soil conditions across the chronosequence (Frouz et al., 2013). 
480 In our study, however, soil conditions and the plant community are distinct between reclaims and

481 surrounding rangeland, even after comparatively greater periods of time. It may be that in

482 northern plains rangelands the presence of plants alone is sufficient for nematode colonization

483 and persistence regardless of the dissimilarity between the two plant communities. This suggests

484 that within more northern prairies, plant species identity may not matter as much as the presence

485 of the rhizosphere and its associated resources; the observed impacts of bare ground but not plant

486 cover type on the nematode community support this possibility. Similarly, a study in New

487 Zealand grasslands found only weak and inconsistent effects on nematode communities in

488 response to selective removal of $\mathrm{C} 3, \mathrm{C} 4$ or all plants, with the strongest observed responses

489 found in bare ground devoid of plant cover (Wardle et al., 1999).

It is important to note that our study did not examine changes in nematode community

491

492

493

494

495

496

497

498

499

500

501

502

composition at the genus or species level, so it is possible that while functionally similar, the

nematode communities found on reclaims may be taxonomically distinct from those on adjacent

rangeland. Nematode functional-level data are often used in ecological studies because they

reflect ecological processes and are considerably less time-intensive to collect than species-level

data. However, functional groups may not always capture shifts in community dynamics in

response to environmental gradients. For example, a study by Porazinska et al. (2003) found that

while nematode trophic groups were resistant to changes in plant diversity, abundances of one

root herbivorous nematode genus did differ across treatments. Future work may therefore

benefit from finer taxonomic detail, either at the family level and employing various index

approaches (such as the Maturity Index; Bongers \& Ferris 1999) or through the use of new DNA sequencing methods (such as in Ramirez et al. 2014). Despite our lack of finer taxonomic detail, the apparent recovery of nematode community functional composition in our system is

PeerJ reviewing PDF | (2018:08:30920:2:0:NEW 14 Apr 2019) 
503 promising, especially given the importance of functions nematodes provide to terrestrial

504 ecosystems (Lavelle et al., 1997; Sylvain \& Wall, 2011).

505

506

507

508

509

510

511

512

513

514

515

516

517

518

519

520

521

522

523

524

525

\section{Soil-plant-nematode interactions}

Regressions and SEM illustrate how soil conditions and the biotic community (both plants and nematodes) interact. These analyses highlight the importance of soil conditions to reclamation success, as soils were the most important factor found to explain observed responses in the biotic community in a majority of cases. Regression reflected ANOVA results and revealed salts and SOM were related to the cover of most plant groups. High sodium concentrations in reclaim soils suggest that environmental filters limit the ability of native plant species to colonize and/or establish in the reclaimed area from adjacent, intact landscapes.

Increased soil salinity has been well documented to limit plant growth through inhibited nutrient uptake (Hu \& Schmidhalter, 2005) and restoration of extremely saline soils may be technically difficult or costly (see Barrett-Lennard, 2002; Pannell \& Ewing, 2006). The influence of SOM on plant communities was also found using SEM. Other work in this region has highlighted the importance of SOM in slowing the recovery of reclaimed sites to reference conditions: Viall et al. (2014) observed reduced SOM content on reclaimed road soils, and they proposed that this limited soil microbial community development and decreased the habitat suitability of reclaims for plant production. While we did not observe differences in SOM between reclaims and undeveloped rangeland, it is possible that SOM levels interact with salt-induced nutrient limitation to influence plant community dynamics. The strong influence of soil characteristics on native plant establishment in reclaims may be limited by environmental filters as well as dispersal (discussed above). Restoring plant communities to reference conditions on these sites will require multiple approaches to be successful. This may entail several seed applications with 
526 increased species diversity (although repeated seeding with similar seed mixes did not appear to

527 influence richness in a greenhouse study; Wilsey and Stirling 2007) and mitigating salinity either

528 by excavating the salt layer or by phytoremediation (e.g., Aschenbach, 2006). In contrast to plant

529 communities, nematode communities responded less strongly to soil conditions and appear to be

530 affected more directly by shifts in resource availability. Regression showed nematode

531 abundances were weakly related to SOM levels, but SEM showed a significant effect only of

532 bare ground on the nematode community. SOM and bare ground were highly correlated (Pearson

$533 \mathrm{r}=-0.43, \mathrm{P}=0.005)$. It is likely that these results indicate the importance of SOM and bare

534 ground to the detrital energy pathway (which includes bacterivorous and fungivorous nematodes)

535 and root resources critical to the herbivory energy pathway components of the soil food web

536 (e.g., Moore and de Ruiter, 2012). Although root herbivorous, fungivorous and bacterivorous

537 nematode abundances did not differ significantly between reclaims and undeveloped rangeland,

538 they did trend lower on reclaims. Across these three groups, the trend in reduced abundances

539 may lead to reduced numbers of omnicarnivores due to prey limitation and consequently to

540 reduced abundances of the overall nematode community present on reclaims.

\section{Conclusion}

Hilderbrand, Watts \& Randle (2005) note that while attempting to create a carbon copy

543 of reference ecosystems through restoration is likely an unachievable goal, because the

544 conditions present at the start of reclamation (landscape degradation) are fundamentally different

545 from those governing community succession after less dramatic disturbances. The authors

546 instead suggest that reclamation should aim to recover the ecosystem to the best possible extent,

547 opting for functional rather than taxonomic recovery when necessary, with resilience to future

548 disturbance in mind (Hilderbrand, Watts \& Randle, 2005). This would enable reclaimed areas to 
549 provide a comparable suite of functions and minimize impacts of fragmentation and invasive

550 species (see Allred et al., 2015) while dynamics of plant community assembly and soil formation

551 proceed over time to restore species diversity and cover through natural processes. Our multi-

552 trophic approach demonstrates that soils, plants, and nematodes recover to reference states at

553 different rates. Soils were linked to the slow recovery of the plant community. Plant presence

554 rather than plant identity mattered more to the nematode community, and soil characteristics did

555 not appear to limit nematodes. Our results suggest increased seeding rates and diversity of native

556 plant species will improve recovery. Additionally, the incorporation of soil amendments to

557 address salinity and nutrient availability may help mitigate environmental filters that contribute

558 to poor native plant establishment on reclaims and inhibit successful recovery of ecological

559 communities and their function. Our study shows that every community may have an

560 idiosyncratic response to reclamation, contrary to the "field of dreams" presumption

561 (Hilderbrand, Watts \& Randle, 2005) prevalent in both reclamation and restoration practice.

\section{Acknowledgements}

563 We thank M. O’Mara for her assistance with site selection and sampling, N. Davidson, K. Hauri

564 and C. Schilling for assistance with field sampling, the Watford City office of the U.S. Forest

565 Service for their assistance with site selection and background information and J. Gaskin for

566 helpful comments on an earlier manuscript draft.

\section{References}

Allred BW., Smith WK., Twidwell D., Haggerty JH., Running SW., Naugle DE., Fuhlendorf SD. 2015. Ecosystem services lost to oil and gas in North America. Science 348:401-402. DOI: $10.1126 /$ science.aaa4785.

Anderson EW. 1986. A guide for estimating cover. Rangelands 8:236-238. 
572

573

574

575

576

577

578

579

580

581

582

583

584

585

586

587

588

589

590

591

592

593

594

595

596

597

598

599

600

601

602

603

604

605

Andriuzzi WS., Wall DH. 2018.Grazing and resource availability control soil nematode body size and abundance-mass relationships in semi-arid grassland. Journal of Animal Ecology 87:1407-1417. DOI: $10.1111 / 1365-2656.12858$

Aschenbach TA. 2006. Variation in growth rates under saline conditions of Pascopyrum smithii (Western Wheatgrass) and Distichlis spicata (Inland Saltgrass) from different source populations in Kansas and Nebraska: Implications for the restoration of salt-affected plant commun. Restoration Ecology 14:21-27. DOI: 10.1111/j.1526-100X.2006.00101.x.

Aziz FP., Champa T., VanderBusch D. 2006. Soil survey of McKenzie County, North Dakota.

Baer SG., Heneghan L., Eviner VT. 2012. Applying soil ecological knowledge to restore ecosystem services. In: Wall DH ed. Soil ecology and ecosystem services. Oxford, UK: Oxford University Press, 377-393.

Baermann G. 1917. Eine einfache methode zur auffindung von ankylostomum (nematoden) larven in erdproben. Geneesk Tijdschr Ned-Indie 57:131-137.

Barker WT., Whitman WC. 1988. Vegetation of the northern Great Plains. Rangelands 10:266272.

Barrett JE., Virginia RA., Wall DH., Doran PT., Fountain AG., Welch KA., Lyons WB. 2008. Persistent effects of a discrete warming event on a polar desert ecosystem. Global Change Biology 14:2249-2261. DOI: 10.1111/j.1365-2486.2008.01641.x.

Barrett-Lennard EG. 2002. Restoration of saline land through revegetation. Agricultural Water Management 53:213-226. DOI: 10.1016/S0378-3774(01)00166-4.

Bassett IE., Simcock RC., Mitchell ND. 2005. Consequences of soil compaction for seedling establishment: Implications for natural regeneration and restoration. Austral Ecology 30:827-833. DOI: 10.1111/j.1442-9993.2005.01525.x.

Bates D., Mächler M., Bolker BM., Walker SC. 2015. Fitting linear mixed-effects models using lme4. Journal of Statistical Software 67:1-48. DOI: 10.18637/jss.v067.i01.

Bongers T., Ferris H. 1999. Nematode community structure as a bioindicator in environmental monitoring. Trends in Ecology and Evolution 14:224-228. DOI: 10.1016/S01695347(98)01583-3.

Dietz H., Edwards PJ. 2006. Recognition that causal processes change during plant invasion helps explain conflicts in evidence. Ecology 87:1359-1367. DOI: 10.1890/00129658(2006)87[1359:RTCPCD]2.0.CO;2.

Dufrene M., Legendre P. 1997. Species assemblages and indicator species: the need for a flexible assymetrical approach. Ecological Monographs 67:345-366. DOI: 10.1890/00129615(1997)067[0345:SAAIST]2.0.CO;2.

PeerJ reviewing PDF | (2018:08:30920:2:0:NEW 14 Apr 2019) 
606

607

608

609

610

611

612

613

614

615

616

617

618

619

620

621

622

623

624

625

626

627

628

629

630

631

632

633

634

635

636

637

638

Emam TM., Espeland EK., Rinella MJ. 2014. Soil sterilization alters interactions between the native grass Bouteloua gracilis and invasive Bromus tectorum. Journal of Arid Environments 111:91-97. DOI: 10.1016/j.jaridenv.2014.08.006.

Espeland EK., Hendrickson J., Toledo D., West NM., Rand TA. 2017. Soil chemistry affects revegetation establishment with and without cover crops in northern mixed grass prairie after energy development. Ecological Restoration 35:311-319.

Espeland EK., Perkins L. 2017. Weed establishment and persistence after water pipeline installation and reclamation in the mixed grass prairie of western North Dakota. Ecological Restoration 35:303-310.

Espeland EK., Perkins LB. 2013. Annual cover crops do not inhibit early growth of perennial grasses on a disturbed restoration soil in the northern great plains, USA. Ecological Restoration 31:69-78. DOI: 10.3368/er.31.1.69.

Fierer N., Jackson RB. 2006. The diversity and biogeography of soil bacterial communities. Proc Natl Acad Sci U S A 103:626-31. DOI: 10.1073/pnas.0507535103.

Freckman DW., Mankau R., Ferris H. 1975. Nematode community structure in desert soils: Nematode recovery. Journal of Nematology 7:343-346.

Frouz J., Veronika J., Cajthaml T., Pizl V., Tajovsky K., Hanel L., Buresova A., Simackova H., Kolarikova K., Franklin J., Nawrot J., Groninger JW., Stahl PD. 2013. Soil biota in postmining sites along a climatic gradient in the USA: Simple communities in shortgrass prairie recover faster than complex communities in tallgrass prairie and forest. Soil Biology and Biochemistry 67:212-225.

Garcia-Palacios P., Shaw EA., Wall DH., Hattenschwiler S. 2017. Contrasting mass-ratio vs. niche complementarity effects on litter $\mathrm{C}$ and $\mathrm{N}$ loss during decomposition along a regional climatic gradient. Journal of Ecology 105:968-978. DOI: 10.1111/1365-2745.12730.

Grace JB. 2006. Structural equation modeling and natural systems. New York, USA: Cambridge University Press. DOI: 10.1086/586991.

Grime JP., Mackey JML. 2002. The role of plasticity in resource capture by plants. Evolutionary Ecology 16:299-307. DOI: 10.1023/A:1019640813676.

Hilderbrand RH., Watts AC., Randle AM. 2005. The myths of restoration ecology. Ecology and Society 10:19.

Hobbs RJ., Harris JA. 2001. Restoration ecology: Repairing the earth's ecosystems in the new millennium. Restoration Ecology 9:239-246. DOI: 10.1046/j.1526100X.2001.009002239.x. 
639 Hothorn T., Bretz F., Westfall P. 2008. Simultaneous inference in general parametric models. Biometrical Journal 50:346-363. DOI: 10.1002/bimj.200810425.

641

642

643

644

645

646

647

648

649

650

651

652

653

654

655

656

657

658

659

660

661

662

663

664

665

666

667

668

669

670

671

Hu Y., Schmidhalter U. 2005. Drought and salinity: A comparison of their effects on mineral nutrition of plants. Journal of Plant Nutrition and Soil Science 168:541-549. DOI: 10.1002/jpln.200420516.

Johnson JR., Larson GE. 2007. Grassland plants of South Dakota and the northern Great Plains. Brookings, SD: South Dakota State University College of Agriculture and Biological Sciences.

Kuznetsova A., Brockhoff P., Christensen R. 2016. lmerTest: Tests in linear mixed effects models. $R$ package version 3.0.0:https://cran.r-project.org/package=lmerTest.

Larson G., Johnson J. 2007. Plants of the Black Hills and Bear Lodge Mountains. Brookings, SD: South Dakota State University College of Agriculture and Biological Sciences.

Lavelle P., Bignell D., Lepage M., Wolters W., Roger P., Ineson P., Heal OW., Dhillion S. 1997. Soil function in a changing world : the role of invertebrate ecosystem engineers. European Journal of Soil Biology 33:159-193. DOI: 35400007052344.0010.

Lawrence JM., Samways MJ., Kelly JA., Henwood J. 2013. Beyond vegetation-based habitat restoration for a threatened giant Spirostreptid millipede. Journal of Insect Conservation 17:557-564. DOI: 10.1007/s10841-012-9541-9.

McSorley R., Frederick JJ. 2004. Effect of extraction method on perceived composition of the soil nematode community. Applied Soil Ecology 27:55-63. DOI:

10.1016/j.apsoil.2004.02.005.

Menta C. 2012. Soil fauna diversity - Function, soil degradation, biological indices, soil restoration. In: Lameed GA ed. Biodiversity conservation and utilization in a diverse world. InTech, 59-94. DOI: dx.doi.org/10.5772/51091.

Mitchell RJ. 1992. Testing evolutionary and ecological hypotheses using path analysis and structural equation modelling. Functional Ecology 6:123-129. DOI: 10.2307/2389745.

Moore JC., de Ruiter, PC. 2012. Energetic Food Webs: An analysis of real and model ecosystems. OUP Oxford.

Murphy CA., Foster BL. 2014. Soil properties and spatial processes influence bacterial metacommunities within a grassland restoration experiment. Restoration Ecology 22:685691. DOI: $10.1111 /$ rec.12127.

Neher DA. 2001. Role of nematodes in soil health and their use as indicators. Journal of Nematology 33:161-168.

PeerJ reviewing PDF | (2018:08:30920:2:0:NEW 14 Apr 2019) 
672

673

674

675

676

677

678

679

680

681

682

683

684

685

686

687

688

689

690

691

692

693

694

695

696

697

698

699

700

701

702

703

704

NRCS. 2006. Agropyron cristatum plant fact sheet. USDA NRCS Idaho State Office, Boise, ID.

Oksanen J., Blanchet F., Kindt R., Legendre P., O'Hara R. 2016. Vegan: community ecology package. $R$ package 2.3-3:Available at: https://cran.r-project.org/web/packa. DOI: 10.4135/9781412971874.n145.

Pannell DJ., Ewing MA. 2006. Managing secondary dryland salinity: Options and challenges. In: Agricultural Water Management. 41-56. DOI: 10.1016/j.agwat.2005.07.003.

Porazinska DL., Bardgett RD., Blaauw MB., Hunt H. William WW., Parsons AN., Seastedt TR., Wall DH. 2003. Relationships at the aboveground-belowground interface: Plants, soil biota, and soil processes. Ecological Monographs 73:377-395. DOI: 10.1890/00129615(2003)073[0377:RATAIP]2.0.CO;2.

Preston TM. 2015. Presence and abundance of non-native plant species associated with recent energy development in the Williston Basin. Environmental Monitoring and Assessment 187:200.

Pywell RF., Bullock JM., Roy DB., Warman L., Walker KJ., Rothery P. 2003. Plant traits as predictors of performance in ecological restoration. Journal of Applied Ecology 40:65-77. DOI: $10.1046 /$ j.1365-2664.2003.00762.x.

R Development Core Team. 2016. R: A Language and Environment for Statistical Computing. R Foundation for Statistical Computing, Vienna, Austria. https://R-project.org

Ramirez KS, Leff JW., Barberan A., Bates ST., Betley, J., Crowther TW., Kelly EF., Oldfield EE., Shaw EA., Steenbock C., Bradford MA., Wall DH., Fierer N. 2014. Biogeographic patterns in below-ground diversity in New York's Central Park are similar to those observed globally. Proceedings of the Royal Society B 281:20141988. DOI: 10.1098/rspb.2014.1988.

Richardson DM., Pyšek P., Rejmánek M., Barbour MG., Dane Panetta F., West CJ. 2000. Naturalization and invasion of alien plants: Concepts and definitions. Diversity and Distributions 6:93-107. DOI: 10.1046/j.1472-4642.2000.00083.x.

Roberts DW. 2016. labdsv: Ordination and multivariate analysis for ecology. R package version $1.8-0$.

Rosseel Y. 2012. lavaan: An R package for structural equation modeling. Journal of Statistical Software 48:1-36. DOI: 10.18637/jss.v048.i02.

Schuman GE. 2002. Mined land reclamation in the northern Great Plains: Have we been successful? In: 2002 National Meeting of the American Society of Mining and Reclamation. $842-865$. 
705

706

707

708

709

710

711

712

713

714

715

716

717

718

719

720

721

722

723

724

725

726

727

728

729

730

731

732

733

734

735

736

737

738

Simmers SM., Galatowitsch SM. 2010. Factors affecting revegetation of oil field access roads in semiarid grassland. Restoration Ecology 18:27-39. DOI: 10.1111/j.1526100X.2010.00716.x.

Snyder BA., Hendrix PF. 2008. Current and potential roles of soil macroinvertebrates (earthworms, millipedes, and isopods) in ecological restoration. Restoration Ecology 16:629-636. DOI: 10.1111/j.1526-100X.2008.00484.x.

Spellerberg I. 1998. Ecological effects of roads and traffic: a literature review. Global Ecology and Biogeography 7:317-333. DOI: 10.1046/j.1466-822x.1998.00308.x.

Stubbendieck J., Hatch S., Butterfield C. 1997. North American range plants. Lincoln, NE: University of Nebraska Press.

Suding KN. 2011. Toward an era of restoration in ecology: Successes, failures, and opportunities ahead. Annual Review of Ecology, Evolution, and Systematics 42:465-487. DOI: 10.1146/annurev-ecolsys-102710-145115.

Sylvain ZA., Mosseler A. 2017. Use of shrub willows (Salix spp.) to develop soil communities during coal mine restoration. Canadian Journal of Forest Research 47:1687-1694. DOI: 10.1139/cjfr-2017-0196.

Sylvain ZA., Wall DH. 2011. Linking soil biodiversity and vegetation: Implications for a changing planet. American Journal of Botany 98:517-527. DOI: 10.3732/ajb.1000305.

Trombulak SC., Frissell CA. 2000. Review of ecological effects of roads on terrestrial and aquatic communities. Conservation Biology 14:18-30. DOI: 10.1046/j.15231739.2000.99084.x.

Viall EM., Gentry LF., Hopkins DG., Ganguli AC., Stahl P. 2014. Legacy effects of oil road reclamation on soil biology and plant community composition. Restoration Ecology 22:625-632. DOI: 10.1111/rec.12115.

Wall-Freckman D., Huang SP. 1998. Response of the soil nematode community in a shortgrass steppe to long-term and short-term grazing. Applied Soil Ecology 9:39-44. DOI: 10.1016/S0929-1393(98)00051-1.

Wardle DA., Bardgett RD., Klironomos JN., Setala H., van der Putten WH., Wall DH. 2004. Ecological linkages between aboveground and belowground biota. Science 304:1629-1633. DOI: $10.1126 /$ science. 1094875 .

Wardle DA., Bonner KI., Barker GM., Yeates GW., Nicholson KS., Bardgett RD., Watson RN., Ghani A. 1999. Plant removals in perennial grassland: Vegetation dynamics, decomposers, soil biodiversity, and ecosystem properties. Ecological Monographs 69:535-568. DOI: $10.2307 / 2657230$. 
739

740

741

742

743

744

745

746

747

Wilsey B., Stirling G. 2007. Species richness and evenness respond in a different manner to propagule density in developing prairie microcosm communities. Plant Ecology 190:259273. DOI: $10.1007 / \mathrm{s} 11258-006-9207-4$.

Wodika BR., Baer SG. 2015. If we build it, will they colonize? A test of the field of dreams paradigm with soil macroinvertebrate communities. Applied Soil Ecology 91:80-89. DOI: 10.1016/j.apsoil.2015.02.005.

Yeates GW., Bongers T., De Goede RG., Freckman DW., Georgieva SS. 1993. Feeding habits in soil nematode families and genera-an outline for soil ecologists. Journal of nematology 25:315-331. 


\section{Table $\mathbf{1}$ (on next page)}

ANOVA and regression results for plant community variables.

All ANOVA testing conducted on 2 and 26 degrees of freedom with sampling location (reclaim, 50 and $150 \mathrm{~m}$ native prairie transects) as a fixed effect. Significant ANOVA results indicate response variables differ across sampling locations. 


\begin{tabular}{|c|c|c|c|c|c|c|}
\hline Response variable & ANOVA F-statistic & $\mathbf{P}$ & Initial regression model & Final regression model & $\mathbf{P}$ & $\mathbf{R}^{2}$ \\
\hline Species richness (total) & 7.28 & 0.003 & Salts & --- & --- & --- \\
\hline Species richness (native) & 13.65 & $<0.0001$ & Salts $+\%$ Exotic Cover & - \% Exotic Cover & 0.0001 & 0.3 \\
\hline Species richness (exotic) & 10.98 & 0.0003 & Salts $+\%$ Exotic Cover & Salts $+\%$ Exotic Cover & 0.0009 & 0.27 \\
\hline Native plant cover & 21.41 & $<0.0001$ & Salts & --- & --- & --- \\
\hline Proportion exotic plant cover & 6.04 & 0.007 & SOM & --- & --- & --- \\
\hline Ruderal plant cover & 11.47 & 0.0003 & SOM + Salts + Bare & Bare & 0.001 & 0.24 \\
\hline Forb cover & 1.45 & 0.25 & Salts + SOM + Silt & Silt & 0.019 & 0.13 \\
\hline Carex filifolia & 8.75 & 0.001 & Sodium & - Sodium & 0.02 & 0.14 \\
\hline Bouteloua gracilis & 12.93 & 0.0001 & Calcium + CEC & - CEC & 0.04 & 0.1 \\
\hline Elymus trachycaulus & 8.36 & 0.002 & Salts $+\mathrm{SOM}+\mathrm{pH}$ & - SOM & 0.045 & 0.1 \\
\hline Agropyron cristatum & 10.56 & 0.0004 & SOM & --- & --- & --- \\
\hline
\end{tabular}




\section{Table 2 (on next page)}

ANOVA results for soil characteristics.

All ANOVA testing conducted on 2 and 26 degrees of freedom with sampling location (reclaim, 50 and $150 \mathrm{~m}$ native prairie transects) as a fixed effect. Significant ANOVA results indicate response variables differ across sampling locations. 


\begin{tabular}{|c|c|c|c|c|c|c|c|c|c|c|c|}
\hline \multirow[b]{2}{*}{ Soil factor } & \multirow[b]{2}{*}{ F-statistic } & \multirow[b]{2}{*}{$\mathrm{P}$} & \multicolumn{3}{|c|}{$150 \mathrm{~m}$} & \multicolumn{3}{|c|}{$50 \mathrm{~m}$} & \multicolumn{3}{|c|}{ Reclaim } \\
\hline & & & mean $\pm S E$ & Max. & Min. & mean \pm SE & Max. & Min. & mean $\pm \mathrm{SE}$ & Max. & Min. \\
\hline pH & 7.88 & 0.002 & $7.5 \pm 0.13 b$ & 8.1 & 6.7 & $7.6 \pm 0.10 \mathrm{~b}$ & 8 & 6.8 & $7.9 \pm 0.04 a$ & 8.3 & 7.7 \\
\hline Organic matter (\%) & 2.01 & 0.15 & $5.19 \pm 0.44$ & 7.25 & 2.25 & $5.24 \pm 0.34$ & 7.7 & 2.75 & $4.13 \pm 0.56$ & 10.3 & 1.45 \\
\hline CEC (meq / 100g) & 13.4 & $<0.0001$ & $23.11 \pm 1.11 b$ & 28.4 & 13.1 & $24.29 \pm 1.33 b$ & 29.75 & 13.45 & $28.21 \pm 1.03 a$ & 34.35 & 17.45 \\
\hline $\mathrm{Ca}$ (ppm) & 8.39 & 0.0015 & $3465 \pm 231 b$ & 4485 & 1741 & $3727 \pm 261 b$ & 4811 & 1721 & $4343 \pm 143 a$ & 4940 & 2967 \\
\hline $\mathrm{Na}$ (ppm) & 5.04 & 0.014 & $85.5 \pm 37.7 b$ & 539 & 8.5 & $90.5 \pm 46.2 b$ & 674 & 9.5 & $244 \pm 72.5 a$ & 755 & 13.5 \\
\hline Soluble salts (dS / m) & 5.16 & 0.013 & $0.35 \pm 0.06 b$ & 1 & 0.16 & $0.39 \pm 0.12 b$ & 1.9 & 0.14 & $0.78 \pm 0.19 a$ & 2.1 & 0.18 \\
\hline Nitrate (ppm) & 0.91 & 0.42 & $3.76 \pm 1.88$ & 27.7 & 0.6 & $2.72 \pm 0.96$ & 11.95 & 0.5 & $3.39 \pm 1.05$ & 15.1 & 0.7 \\
\hline Sand (\%) & 0.35 & 0.71 & $24.89 \pm 4.03$ & 69 & 9 & $25.32 \pm 3.7$ & 67.5 & 13 & $27.07 \pm 4.44$ & 71.5 & 12 \\
\hline Silt (\%) & 10.57 & 0.004 & $43.11 \pm 2.6 a$ & 54 & 16 & $41.75 \pm 2.31 a$ & 54 & 17.5 & $35.43 \pm 2.48 b$ & 47 & 13.5 \\
\hline Compact. $7.5 \mathrm{~cm}$ (MPa) & 0.98 & 0.39 & $1.06 \pm 0.15$ & 1.98 & 0.42 & $1.05 \pm 0.14$ & 1.72 & 0.43 & $1.14 \pm 0.17$ & 1.93 & 0.23 \\
\hline Compact. $15 \mathrm{~cm}$ (MPa) & 6.35 & 0.006 & $1.18 \pm 0.15 b$ & 1.94 & 0.52 & $1.23 \pm 0.17 b$ & 2.16 & 0.53 & $1.43 \pm 0.18 a$ & 2.44 & 0.34 \\
\hline Soil moisture $(\% \mathrm{w} / \mathrm{w})$ & 2.77 & 0.081 & $26.7 \pm 1.5$ & 38.2 & 15.1 & $26.8 \pm 1.7$ & 45 & 16.3 & $24.1 \pm 1.4$ & 34.7 & 14.7 \\
\hline
\end{tabular}




\section{Table 3 (on next page)}

ANOVA and regression results for nematode community abundance.

All ANOVA testing conducted on 2 and 26 degrees of freedom with sampling location (reclaim, 50 and $150 \mathrm{~m}$ native prairie transects) as a fixed effect. Significant ANOVA results indicate response variables differ across sampling locations. For regression models investigating interactions between nematodes, plant and soil factors, CAFI, AGCR and BOGR correspond to species codes for the plants threadleaf sedge, crested wheatgrass and blue grama, respectively. 


\begin{tabular}{lcccccc}
\hline Response variable & F-statistic & $\mathbf{P}$ & Initial regression model & Final model & $\mathbf{P}$ & $\mathbf{R}^{\mathbf{2}}$ \\
\hline Total nematodes & 3.4 & 0.049 & CAFI + Salts + pH + Bare & $\mathrm{pH}$ - Bare & 0.008 & 0.22 \\
Bacterivores & 0.78 & 0.47 & $\mathrm{AGCR}+\mathrm{SOM}+$ Litter + Salts + pH & $\mathrm{SOM}$ & 0.01 & 0.15 \\
Fungivores & 1.96 & 0.16 & SOM + Salts + pH + Litter & $\mathrm{SOM}$ & 0.006 & 0.18 \\
Root herbivores & 2.42 & 0.11 & Salts + pH + Bare & $\mathrm{pH}-$ Bare & 0.006 & 0.19 \\
Omnicarnivores & 4.98 & 0.015 & BOGR + CAFI + Salts + pH & CAFI & 0.004 & 0.19 \\
\hline
\end{tabular}


Figure 1 (on next page)

Boxplots of selected plant indicator species.

Indicators are characteristic of A) 150 m sampling locations (Carex filifolia, threadleaf sedge);

B) $50 \mathrm{~m}$ sampling locations (Bouteloua gracilis, blue grama); and C) an invasive plant (Agropyron cristatum, crested wheatgrass) and D) a native plant (Distichlis spicata, desert saltgrass) from reclaims ("PAD"). 


\section{PeerJ}
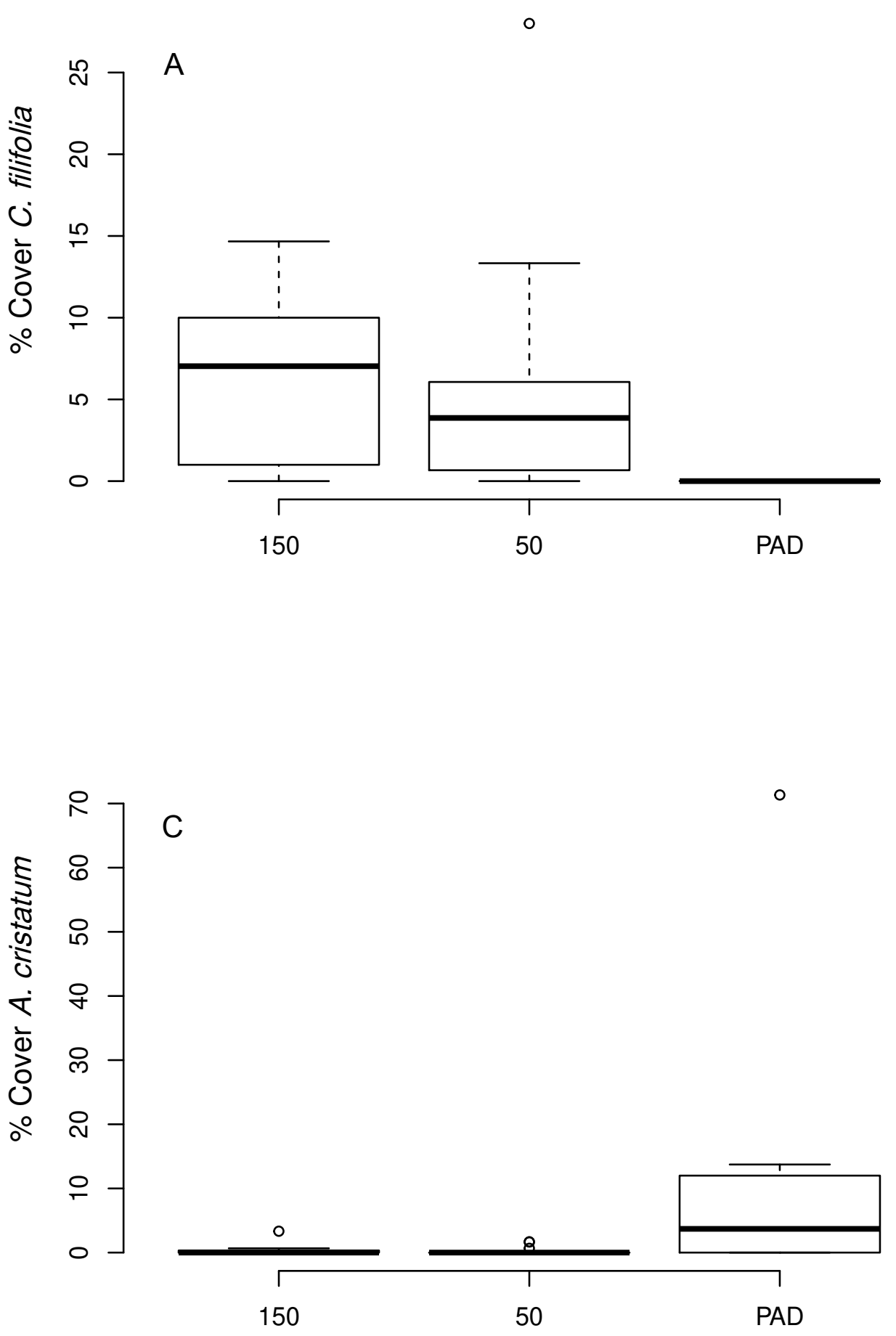
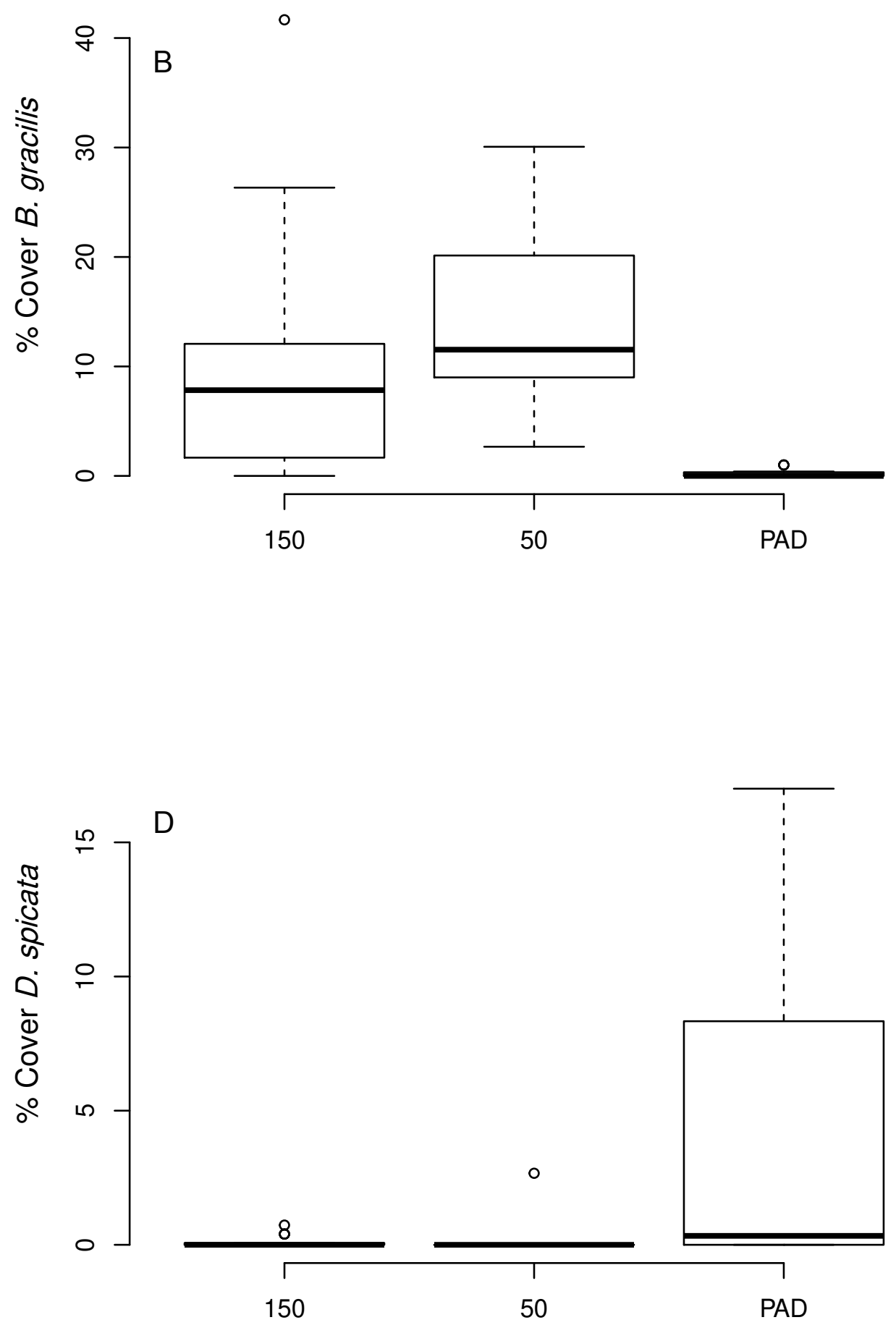
Figure 2 (on next page)

Differences in vegetation cover between reclaims ("PAD") and adjacent, intact rangeland $50 \mathrm{~m}$ and $150 \mathrm{~m}$ from reclaim edges. 

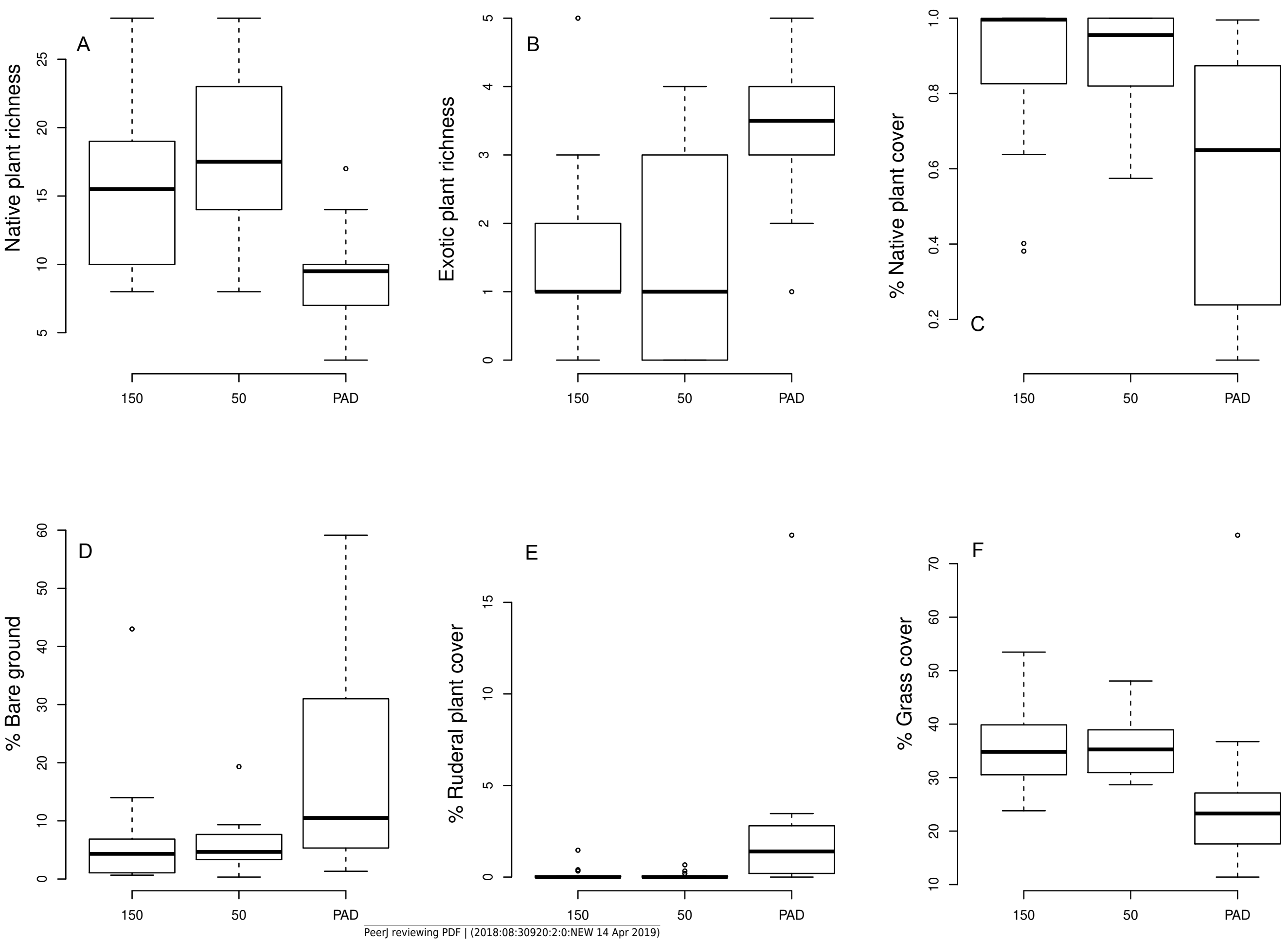
Figure 3 (on next page)

NMS ordination of plant community composition by sampling location.

Open squares represent reclaimed well sites, triangles represent adjacent, intact rangeland $50 \mathrm{~m}$ (filled triangles) and $150 \mathrm{~m}$ (open triangles) from reclaim edges. 


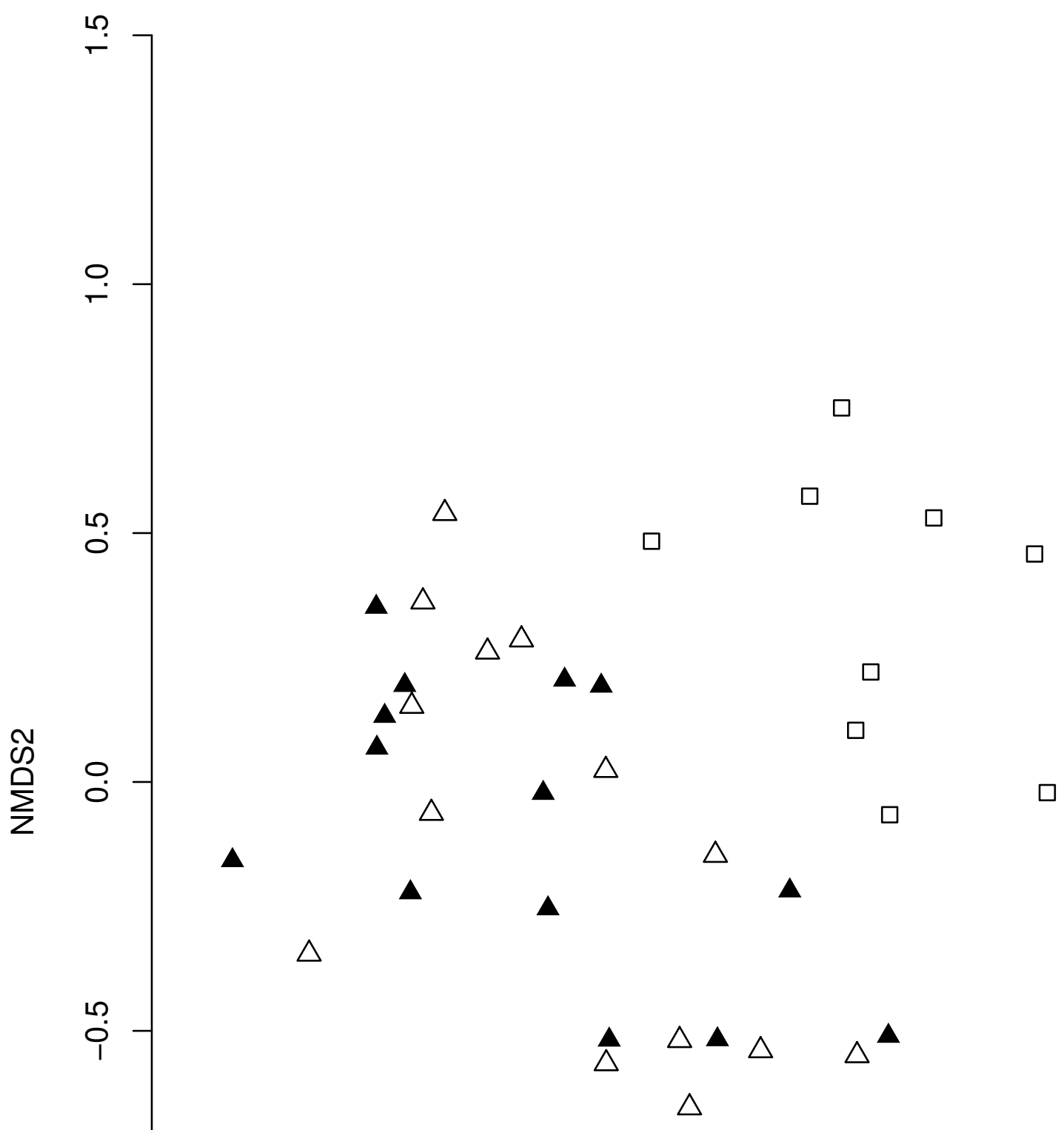

$\triangle 150 \mathrm{~m}$

\begin{tabular}{lll}
$\circ$ & \multicolumn{1}{c}{$50 \mathrm{~m}$} \\
\hline $\mathrm{I}$ & $\square$ & Reclaim
\end{tabular}

$\frac{1}{1}$

\begin{tabular}{|ccccc|c|}
\hline & 1 & & 1 & 1.5 \\
-1.0 & -0.5 & 0.0 & 0.5 & 1.0 & 1.5 \\
\hline Peer) reviewing PDF I (2018:08:30920:2:0:NEW & 14 Apr 2019) & NMDS1 & & &
\end{tabular}


Figure 4 (on next page)

Boxplots comparing soil abiotic factors between reclaims ("PAD") and adjacent, intact rangeland $50 \mathrm{~m}$ and $150 \mathrm{~m}$ from reclaim edges. 
Figure $\mathbf{5}$ (on next page)

Boxplots comparing select nematode groups between reclaims ("PAD") and adjacent, intact rangeland $50 \mathrm{~m}$ and $150 \mathrm{~m}$ from reclaim edges.

Note that as omni-carnivores are comparatively less common members of the nematode community relative to other groups (such as root herbivores) their abundances are an order of magnitude lower than those of total nematode abundances. 
Figure 6

Final fitted model used to estimate strengths of interactions between plant, soil and nematode factors.

Solid lines indicate significant $(P<0.05)$ interactions and dashed line indicates nonsignificant interaction, with values for estimates of standardized path coefficients.

*Note: Auto Gamma Correction was used for the image. This only affects the reviewing manuscript. See original source image if needed for review.

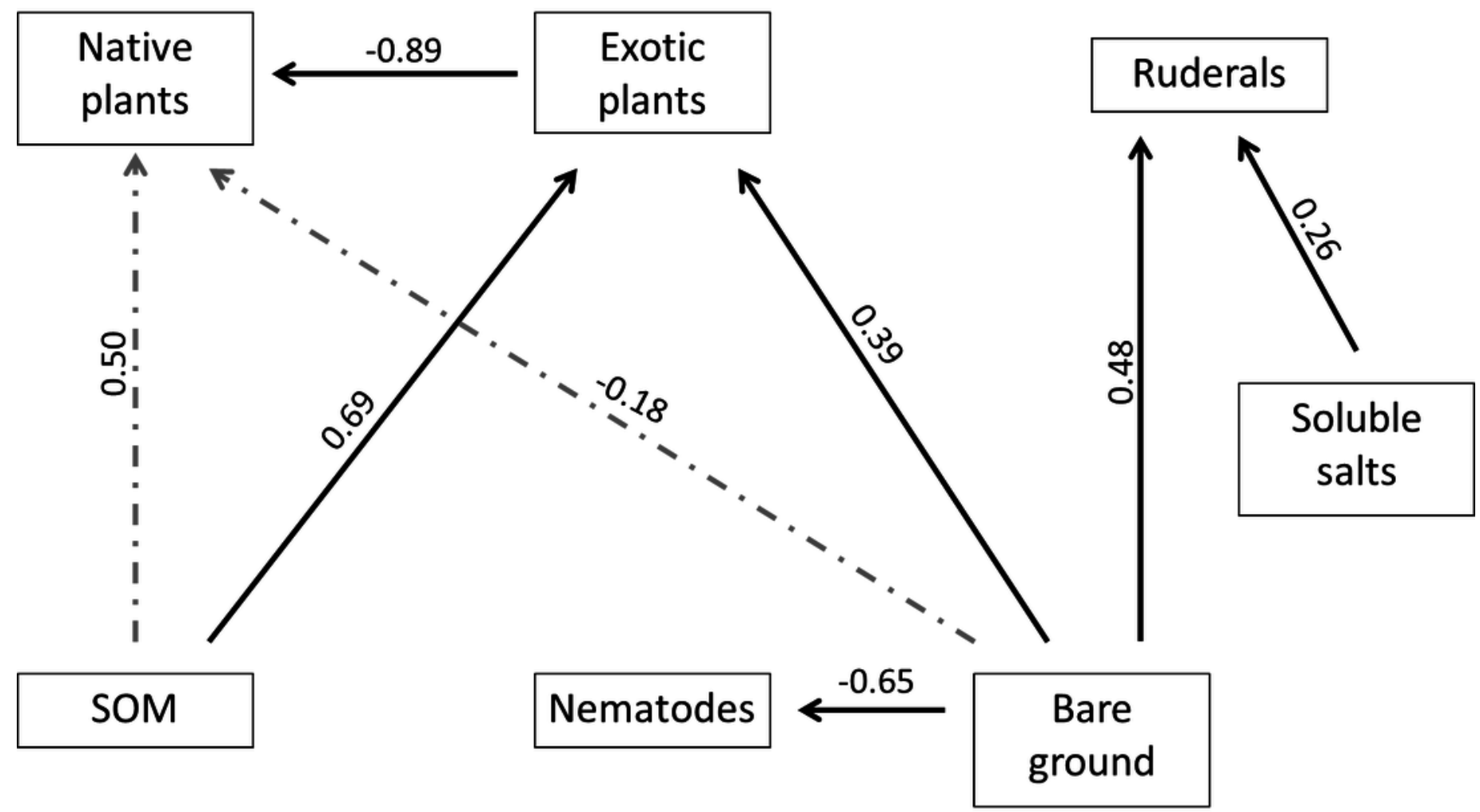

